\title{
Linguistic Predetermination of Conjugal Status of Igbo Women
}

\author{
Ngozi Ezenwa-Ohaeto \\ DOI: http://dx.doi.org/10.4314/ujah.v14i1.2
}

\section{Abstract}

Marriage is often viewed in many cultures as the indispensable avenue towards self- realization. It is conventionally taken to be the essence of womanhood among the Igbo of Nigeria. This research delves into the analysis of some related Igbo philosophical ideologies expressed and ingrained in the linguistic repertoire of Igbo world-view and which have served as an instrument of sustenance and transfer of this culture over generations. It maintains that such linguistic expressions have been used as instruments of mental and physical bondage which have hindered positive change and self-actualisation of the Igbo woman.

\section{Introduction}

Language is a major medium of propagating a people's culture. It usually embodies such a people's ideologies and further exposes the intricate relationships between language and ideology. The two are so intertwined that one cannot critically discuss a people's language without delving into their ideologies. For instance, language serves as the expressive vehicle of ideologies. In order words, ideologies are identified within the structures, style, system and content of the language. With particular reference to discourse events, ideologies are situated and expressed in discourses. That means that "...ideologies reside in text" (Fairclough 71). While trying to explain the tie that exist between language and ideology, Fairclough further notes that; 
...it is true that forms and content of text do bear the imprint of ideological processes and structure, it is not possible to 'read off' ideologies from texts. This is because meanings are produced through interpretation of texts and texts are open to diverse interpretations, and because ideological processes appertain to discourses as whole social events - they are processes between people - not to the texts which are produced, distributed and interpreted as moments of such events (71).

In support of this, Gramcsi postulates that ideologies are "a conception of the world that is implicitly manifest of art, in law, in economic activity and in the manifestations of individual and collective life" (328).

The ideologies of the Igbo in relation to conjugal affairs of women are ingrained in proverbs in addition to other genres. Proverbs, in Igbo land is described as "mmanu e ji eli okwu" (oil with which discourses are eaten). They are so highly appreciated in Igbo culture that one who is versed in them and who applies them appropriately is held in high esteem. Such a man (because it must be a man as women are believed to lack critical minds, and as a result, they do not possess the ability to apply proverbs in discourses) is seen and described as wise. Igbo ideologies are mainly wrapped in proverbs which are elevated to a state of unquestionable 'truth'. They are an embodiment of common sense, and generally accepted to the extent that "the dogmas and pronouncements which they contain are not to be questioned within the community to which they belong" (Schipper 23).On their part, Whittaker and Msiska while citing Lindfors (68) perceived Igbo proverbs as means of supplying "focus on the values of the society.... Proverbs thus provide a 'grammar of 
values' of the society being portrayed. On account of the dominance of the male gender in Igbo culture proverbs are often designed and managed to suit male purposes in sociocultural matters. Igbo culture portrays women as inferior and subordinate to men and such are carefully and consciously built into linguistic expressions and used over generations. Thus, conscious linguistic acts become unconscious linguistic behaviours of the society. Whittaker and Msiska noted that "sexism is such a normal way of thinking that its manifestations go completely undetected" (116).

Since "language can be an instrument of freedom and liberation as well as oppression and dominance" (Chukwukere 252) the male gender shapes language to portray them as powerful and independent and warrants them to form and direct their stance and reality of life against the female gender. The same Igbo linguistic expressions were formed to depreciate women; render them less significant than their male counterparts. As a result, many women feel inadequate, timid, afraid, undecided and dependent, inferior, powerless and in most cases, obscure even in matters concerning them. For instance, in Igbo marriage ceremony women are completely excluded from their own betrothal rites, but women are not allowed in men-only affairs. Whittaker and Msiska used a marriage incident in Chinua Achebe's Things Fall Apart to point to this situation. They observed that during Akueke's marriage rites, she entered:

carrying a wooden dish with three kola nuts and alligator pepper. She gave the dish to her father's eldest brother and then shook hands, very shyly, with the suitor and his relatives... when she had shaken hands, or rather held out her hands to be shaken, she returned to her mother's hut to help with the cooking (108). 
Conversely, Whitaker and Msiska continue,

while the women are excluded from the 'male domain', of community power, men are permitted to intrude into the domestic domain. When his third wife fails to produce her afternoon meal at the prescribed time, Okonkwo goes to her hut, then interrogates his other wives, and eventually beats the delinquent spouse (108)

Chinua Achebe's protagonist in Things Fall Apart, Okonkwo is a typical Igbo man who never missed a single opportunity to showcase the patriarchal tendencies inherent in Igbo culture. His family is his theatre where he often battered his wives at every slightest provocation. Whether the act that led to the so called 'provocation' is enough to demand the resultant battering is a question that requires an answer. For instance, when Ojiugo did not return in time from her friend's house to serve Okonkwo his lunch, Okonkwo was "provoked to justifiable anger" (21). One is not surprised that Chinua Achebe described the anger as 'justifiable' because he himself is a product of patriarchal society, and that was why he could not see the fact that unforeseen circumstances are part of human life. These cultural injustices, in effect, affect women psychologically and limit their potentials, which also result to their feeling of deficient in the ability of achieving self-worth. Whittaker and Msiska aptly captured this imbalance and unevenness in their analysis of gender relation in Chinua Achebe's Umuofia, using allegories. They pointed "the 
Manichean allegories that defines Achebe's society - the sexual allegory of male and female, good and evil, superiority and inferiority, rationality and irrationality, activity and passivity. The frequent association of women with children in the narrative is another manifestation of the allegory" (113114).The allegorical exposition is further made by Fromkin et al, when they noted that:

a businessman's aggressive; a businesswoman's pushy. A businessman's good on details; she's picky....he follows through; she doesn't know when to quit. He stands firm; she's hard....His judgments are her prejudices. He is a man of the world; she's been around. He isn't afraid to say what is on his mind; she's mouthy. He exercises authority diligently; she's power mad. He's close mouthed; she's secretive. He climbed the ladder of success; she slept her way to the top (447).

That is why it is regarded as a very big insult in Igbo culture to describe a man as a woman even when the man is an 'efulefu', a drunk, highly irresponsible, a criminal or a social, religious or political outcast. It does not matter whether it is a woman that feeds and clothes him; he is still superior to the woman. After all, a woman crouches/stoops to urinate: (Nwanyi na erunata ana anyu amiri), therefore, she should not talk where men are gathered. Stooping, in this context, is a sign of low status while standing to urinate symbolizes superiority.

Marriage, for instance, is one of the spheres where proverbs provide social ordinances, which guide marriage activities of the Igbo, particularly, as they affect women. Through proverbs the people's ideologies are "naturalized or authomatized" (Gramsci 324), as social convention. Any attempt by anybody to contravene these 'laws' are seriously 
frowned at. Of course, marriage in Igbo land is an avenue instituted by culture for self-fulfillment and actualisation for women. It is the only source of prestige and honour for them. No matter the height of achievement made by any woman, and she is not married, she faces all sorts of humiliation in the hands of the relations and the society at large. If a married woman is unfortunate to be childless, her case worsens and she stands to lose her prestige, because she has failed in her allimportant obligations: reproduction.

Gramsci explained that "ideology is tied to action, and ideologies are judged in terms of their social effects rather than by their truth values" (324).

Some of these proverbs include:

- Ugwu/Mma nwanyi bu di (Husband/Marriage is the prestige/beauty of a woman).

- Nwanyi gafee onyemuru, a juba onye na-anu (At a point in a woman's life the question is no longer who is the father but who is the husband).

- Di bu Iku na-echebe anya (Husband/Marriage is the eye lashes (man) that protect the eyes (woman)).

- Di bu ndo nwanyi (Husband/Marriage is a woman's shield).

- Ugwu nwanyi bu di nuru ya (A woman's honour/prestige lies in/with the man that marriesk her)

- Nwanyi bu mbanaka enwere mgbologwu (Woman's is a tree branch without roots).

The above are some of the proverbs that make it explicitly clear that the woman cannot be appreciated in isolation from her husband, her achievement in the society notwithstanding. After all, dowry was paid on her making her a property of the man. Therefore, whatever she acquires/achieves, her natural 
endowment and all that she is are made for the pleasure of the man/husband. She is treated as a second fiddle to the man and never as an equal. Simone de Beauvoir agrees completely with this when she said that:

...humanity is male and man defines the woman not in herself but as relative to him....she is the incidental, the inessential as opposed to the essential. He is the Subject, he is the Absolute- she is the Other (16).

These proverbs project the idea that her essence and being lie in her lifelong attachment to a man. Such is not the case with the man. The Igbo society made man an independent and the superior being from childhood. The boy-child, who is expected to continue the lineage of a family, is culturally preferred to the girl-child, who will later be 'sold' to another family, where she is expected to toil all through her life for the propagation of the image of the man and the new family. And as it is culturally known in most Igbo culture, that in spite of all these labouring, she has no inheritance since she herself is an inheritable property. This situation is aptly captured by Emenyi when she asserted that women are simply seen "as part of men's estate" (44). This, inevitably results in unequal and biased treatment and attention given to both sexes. While the boys are trained and equipped for societal challenges ahead, marriage is customarily endorsed as a social obligation for the girls. To prepare her ahead to be a 'good wife', the girl-child is trained on the role of culture instituted covert servitude, docility, biddability, passivity, submissiveness and meekness, to which the mother will be highly extolled to have trained her child 'well'. Okeke, while citing Burne and Devis, rightly sums up the plight of the Ugandan girl-child which is a replica of Nigerian girl-child experience. She writes:

From the moment she takes her first steps, she will be regarded as inherently inferior to her 
brother. She will continually be battling against prejudicial attitudes and unfair work practices in a culture that places little or no value on her contribution to society... more often than not, she is regarded more as a productive piece of property than as a person toiling long hours only for her husband to be paid.(21)

There is no doubt that both naturally and traditionally, each gender has its own roles to play for societal cohesion and mutual existence between the genders. What is completely unacceptable is that many of the practices obtainable, not only in the Igbo society but in most African nations as well and which this paper vehemently criticizes, include what Uko described as "the dominant socio-political structures that exist in the contemporary African society"(130). These structures are systematically established by the male folk "to impede the full development of women's potentials" (130). Uko further asserted that "it is evident that certain paradigms in society apply only to women to make them unable to attain selfrealization and fulfilment (130).

Women are also made to adopt, in the process of socialization, and to "internalize the reigning patriarchal ideology so that they tend to be conditioned to derogate their sex and cooperate in their subordination" (Bashir 67). Although Igbo society also expects everyman to get married too and whoever fails in this capacity is seen as an 'efulefu' (a worthless man), the so-called 'efulefu' is not marginalized or stigmatized the way an unmarried woman is. The "Umunna" (kinsmen) can decide to get him a young and able-bodied wife even when he is old and incapacitated mentally or seriously deformed physically. Of course, the Igbo believe that "nwoke adi njo" (a man is never ugly or too old to marry. He can marry a girl young enough to be his daughter). This 
situation is worse in the rural areas and worse still if the girl involved is not educated and comes from a poor background. She may be used to settle old and huge debts owed by the father, or married to a rich man far much older than she is. If the husband is dead, she can be forced into levirate marriage (widow inheritance by a male relative of the former husband) just to ensure that she stays under a man. Men are never forced into any such social or cultural obligations. Unlike the women, they have choices.

This linguistic situation is not restricted to marriage alone. The 'superiority' of man over woman is clearly expressed and ingrained in the Igbo word, 'nwoke'(male- the great/superior child).The word was formed in such a way that even if it is written inversely i.e'Okenwa', the greatness in the word is still intact. Also the Igbo adjective 'oke' (which is derived from nwoke) is used to qualify other things other than 'nwa' (child), to indicate superiority and greatness of the item being described. Thus you have such expressions as:

- Oke moto (great/mighty/superior car)

- Oke mmadu (a great/mighty/superior man)

- Oke ihe (great/mighty thing or event)

Where 'Oke' qualifies a woman, as in "Oke nwanyi" (great woman), there is usually the undertone of misplaced achievement, implying that ordinarily the woman in question is not expected to be 'great'. 'Oke' therefore depicts generic adjective for superiority, greatness and prejudices against women.

This unequal and lopsided treatment to the sexes is socially enthroned and linguistically entrenched in Igbo traditional society and most often the women themselves are made by tradition to willingly participate in their own exploitation. This is very evident in the institution of "Umuada", a body that is carefully organized and pre- 
structured in such a way that the members (women) carry out some cultural specifics even against themselves. For instance, the Umuada; (Married and unmarried women who often go back to their clan of birth to carry out some cultural obligations) are used by the culture to force fellow women married in the 'umuada' clan of birth into accepting cultural ideological practices even when such are inhuman. For instance, the 'umuada' see to it that a widow's head is cleanshaven during her mourning period. There is no equivalent body to insist on men shaving their heads when their wives die. If a widow is suspected to have a hand in the husband (and often the woman is a suspect when the husband dies), the 'umuada' would see to it that she drinks the water used in bathing the late husband's dead body. A man is never suspected to kill the wife, nor is there anybody or institution to insist that he drinks any water. It is obvious that patriarchy does not favour women but, undoubtedly, it favours men. This is gender hegemony in action. The imbalance in Igbo gender relation moved Njoku note that "patriarchy is a social system controlled by men. Patriarchy results in sexism which attributes importance and superiority to the male and inferiority to the female" (277).

\section{The Extent of the Matter}

Patriarchy and female exploitation are a phenomenon which have bedeviled womanhood and by extension our society, beyond and across profession, race and time transcending religion and education.

With the advent of Western education, when eventually the Igbo man was convinced of the benefit inherent in the foreign culture, it was the male gender that first benefited from it. This is quite evident in "Arrow of God". When Ezeulu sent his son, Oduche to "be my eyes there" (45). Though he has 
girls too, he did not send any of them to school. His action was a manifestation of his society's ideology that the male-child should have everything good, while the girls are groomed and prepared for the pleasure of their future husbands. In those days, too, the girls were married off and their dowries used in training the boys. Over time, this attitude metamorphosed into the normal act of reserving intellectual fields for the males only. They were to become doctors, writers, educationists, lawyers, engineers, name them. And so the titles that describe these areas of knowledge were to be seen as males' too. Fromkim, et al observed that "until recently, most people hearing My cousin is a professor (or a doctor, or the Chancellor of the University, or a steel worker) would assume that the cousin is a man" (448). That also culminated into titles such as 'Bachelor of Arts' (BA), 'Master of Sciences' (BSc).It's never 'Mistress of Arts'(MA) or 'Lady of Sciences' (LSc) Centuries later, and in the turn of both social and economic changes, men started feeling that having illiterate wives was detrimental to their social and economic status. They allowed their daughters to go to school but made sure that the education they got was designed in such a way that it would equip them to serve men better. They were therefore trained to become nurses, seamstresses, typists, school teachers, house-workers and the likes. So that if one says my cousin is (any of the above mentioned professions), you would undoubtably understood that s/he was referring to a woman, not a man. Of course women, as rightly noted by Grace Okereke, "have become late-comers on political, economic and literary spheres" (158) as a result, women became latecomers in the male-reserved professions.

Religiously speaking, the Holy Bible made it clear in Genesis 3:16" "your desire shall be for your husband and he shall rule over you" (NKJV 3:16). Emenyi (39) also noted that such patriarchal cultural pattern is also evident in Islam. For instance, the Koran has it that "Men are the managers of the 
affairs of women for Allah has preferred in bounty one of them over the other" (Sura 4:3) and, of course, the two holy books were instituted not to be questioned or doubted. To do so will amount to 'sacrilege', more so when it comes from a woman. In this state of inequality between the sexes, the woman is always guilty of all evil that befalls man and God. She was a deceiver in the Garden of Eden. In Igbo folklore, she is the greedy one who cut more than she could eat and the sky that served as source of food for mankind since creation (not womankind any way) receded beyond man's reach and ever since, man had to work hard to feed. In one of the Ashanti myth (Ghana), it tells of how man and woman first came together against the will of the creator, surprisingly in this case, they accepted that man initiated the action, but woman will still suffer more than man:

here is the punishment for the men; when a man sees a woman whom his heart desires he will have to give her gold, clothes and many other fine things before he can possess her. And here is the punishment for the woman: since you disobeyed, when you see a man whom your heart desires you will have to keep it to yourself in your head! In addition, you will have to pound the fufu and do all the work, before eating...you will be with child nine to ten months and you shall give birth in great pain (Schipper 25).

The fact that it is not customary for a core Igbo man or an African man to put the female's view into account unless it agrees with theirs is not debatable. Actually a woman is meant to be seen and not heard. In fact, the woman lives in a man's world. 
African mythology (oral literature) continues to create dichotomy between the sexes. In most of them, women are portrayed as the inferior other who must be under a man. It will not be wrong to say that the author of the Christian Bible, the Islamic Quran and the designers of African mythology were all men who had ensured that the content of their stories deeply institutionalized male-dominance over female while using women (as story tellers) to further institutionalize their (men) stories (his-story: history), and women were made to be deeply involved in their exploitation and marginalization under the guise of tradition.

While trying to explore people's views on the issue at hand, Schipper discovered that:

female anthropologists have a little bit tended to idealize the position of women in pre-colonial society, maintaining that men and women were equal before the coming of the Europeans and that inequality was the result of capitalist exploitation by Westerners (e.g. Leacock 1979). African (oral) literature offers no confirmation of such wishful thinking-which does not mean that the reverse is true, and that the position of women in Africa is significantly better as a result of contact with the Western world. There is just a little evidence to support this view, at least in the written literature of Africa. As for the oral tradition, it is often impossible to say whether a certain story or song was made up by a man or a woman. But after carefully examining recorded texts, one does begin to wonder to what extent a certain myth, story, proverb or song is intended to favour or prejudice certain interests within a society (22).

The above report is one among so many that ascertain that from the beginning, patriarchialism is an age long problem 
which has been carefully and systematically fashioned by the male gender against the female gender. The universal tendency of the problem is as disturbing as its persistence and perpetuation.

\section{In Search of Solution}

To search for solution to a problem of this nature is a difficult task. It is difficult given the well-known fact that "old habits die hard". The men folk, or rather we (both men and women) had lived with this cultural situation for so long and have internalized the unequal treatment of the sexes over a very long period of time that everything seems so normal. Even the oppressed are used by the oppressors to sustain and perpetuate the oppression. A situation where "our religious, educational and political institutions promulgate attitudes along sexist biases...patterned behaviour from our unwritten but everpresent cultural files of 'what females do' and 'what males do" (Eakins and Eakins in Emenyi 5).We are now ...gendered persons living in a gendered world, thinking gendered thoughts... "(Hess, et al in Emenyi 10). Since the problem is linguistically oriented, it only seems right to begin the search for solution linguistically.

\section{Some Igbo proverbs say:}

$>$ E mee nwata ka e mere ibe ya, obi adi ya mma (If a child is given the same treatment as his/her peer, he becomes happy).

$>$ Ugwu bu nkwanye nkwanye ( respect is reciprocal)

$>$ Onye bunie aso enu o daa ya n'iru. (One who spits skywards spits on his/her face).

$>$ Nwa muo emegbuna nwa mmadu, ma nwa mmadu emegbuna nwa mmuo (Let the spirit not maltreat the human and vice versa: Golden rule). 
The above are some Igbo proverbs that preach equal treatment to all, male and female inclusive. They are equally in the repertoire of Igbo philosophical ideology which engenders democracy and not patriarchy nor matriarchy, not hegemony but harmony, not suspicion but trust, and not dichotomy but unity. The Igbo nation should emphasize these and jettison the former.

The government on its part should insist on formal education for both sexes to secondary school level. Where formal education may not be provided, at least general enlightenment on basic human rights should be made available to the illiterate women in the hinterlands. The fact that the present generation still upholds those proverbs and other cultural practices that lead to sex dichotomy calls for serious worry. One outstanding and distinctive feature which language and culture share in common is dynamism. Sally acknowledged the fact when she remarked that:

culture consists of repertoires of ideas and practices that are not homogenous but continually changing because of contradictions among them or because of new ideas and institutions are adopted by members.... Cultural discourse legitimate or challenge authority and justify relations of power (11).

Looking at the present Igbo society, some of these practices are actually meeting some levels of resistance from the educated women-class and those that live in the cities, but the fundamental problems are still there. To use the word, 'resistance', is an indication that the problem still persists. The government, as a matter of fact, has promulgated laws to protect its citizens, but one wonders what happens to those who are ignorant of such laws, which some men catch up on and continue to perpetuate crimes against 'womanity'. The so 
much talk on 'women empowerment' should be made more practical and realizable through the creation of fertile ground to nurture such human development projects. Some nongovernmental organizations have taken up the challenge of pushing the enlightenment campaign to the rural dwellers but the economic recession and political interests often create additional challenges for them. While government is advised to support the non-governmental bodies in this all important campaign, it still wholly falls back on government to expose the women in the villages to their rights to ensure that the law takes its proper course, whenever it is necessary. This will in no small measure contribute to women emancipation from inhuman practices such as patriarchy.

The wrong impression created by men is that culture is unquestionable and therefore cannot be changed. Bearing in mind the fact that language, which is a carrier of the culture of the users changes, and knowing the age long maxim that change is a constant phenomenon in life, then society should be flexible enough to allow Igbo and other African ideologies to benefit from the flexibility and dynamism of change. Moreover, men (not generic man, but male gender) seems to put aside the fact that language is formed and reformed by man for the sole purpose to suit their need. Time has come to allow language to also serve the needs of womenfolk.

\section{Conclusion}

This paper has endeavoured to spotlight on the age long predicament of women in Igbo land in particular. It maintains that patriarchy and gender hegemony are inhuman practices that lead to social and economic backwardness on the side of women and moral poverty on the side of men and the society. This research therefore suggests equal treatment and mutual co-existence between the two sexes. It suggests that prestige 
and honour are cultivatable qualities which anybody, no matter the gender can strive to achieve. No gender inherently depends on the other to do so as one of the proverbs cited here suggests. Since language and culture are dynamic, the men-folk should allow the dynamism to have effect on those archaic linguistic expressions that promote women inferiority and their total dependence on men. If I may borrow Emenyi's words, “...no gender is indispensible, as such, both should co-operate and complement each other rather than enforce sex difference"(54). In addition to this, this study makes a clarion call to re-definition and re-creation of Igbo linguistic expressions (proverbs) that will give women a pride of place in the socio-cultural milieu of the Igbo nation of imbalance, which is projected via proverbs. Women should be made to be part of this re-birth. Above all, with the reformed linguistic expressions which will reflect on the Igbo ideology, the female gender will start to enjoy a renewed and better personality as well as feel a sense of belonging in the midst of the male gender. This will also render Igbo sexist-free language. This will boost their ego which will in turn erase the societal imbalance that impedes their social, economical and political advancement. It will also give them the opportunity to contribute their own quota to the development of our dear Igbo land and Nigerian society at large. God almighty, in His infinite wisdom, created all humans equally and endowed Igbo women with their own intellect, identities and pride.

Finally, this research calls for people's circumspection, people's introspection and people's reflection on the issue at hand.

Ngozi Ezenwa-Ohaeto is of the Department of English Language \& Literature, Nnamdi Azikiwe University, Awka.

\section{Works Cited}

Achebe, C. Arrow of God. Nigeria: Heinemann, 1964. 
Bashir, Amina.'Language, Gender and Society: Anti-female Sentiments in Two Nigerian Novels".Ed. Koroye Seiyif and Noel C.Anyadike.Port Harcourt:Pearl Publishers,2004.Woman in the Academy: Festschrift for Prof. Helen Chukwuma.

DuBois, W.E.B. The Souls of Black Folk. Ed. David W. Wright and Robert Gooding Williams Boston; Bedford Books, 1997.

.Emenyi, Imoh .A. Intersection of Gendered Voices. Lagos: Concept Publications Ltd,2005.

Fairclough, N. Critical Discourse Analysis: The critical Study of Language. British: Longman Group Ltd; 1995.

Fromkin , V. Robert Rodman and Nina Hyams. An Introduction to Language. New York: Micheal Rosenberh;2005.

Gramcsi. A. Selections from the Prison Notebooks. Ed .Hoare and G. Nowell Smith, Lawrence and Wishart 1971.

Nelson, Thomas. Holy Bible: "New King James Version". Thomas Nelson Inc: China,1982.

Njoku,Teresa U. "Beyond Phallo-Criticism: Issues and Trends in the Criticism of the Criticism of the African Feminist Novel".Ed. Austin Akpuda. Reconstructing the Canon: Festschrift in Honour of Prof. Charles Nnolim. Skillmark Media Ltd, 2001.

Okeke,C. Cornelia. The Christian Pastoral Challenges of Widowhood Practices among Igbo of Nigeria. Enugu: Victojo Production Services, 2009.

Okereke, Grace E. "African Gender Myths of Vocality and Gender Dialogue in African Literature".Gender Perceptions and Development in Africa. Ed. Mary E. Modupe Kolawole. Lagos: Arrabon Academic Publishers, 1998. 
Sally, E. Merry. Human Rights and Gender Violence: Translating International law into Local Justice. Chicago: University of Chicago Press, 2006.

Schipper, Mineke. Ed. Unheard Words: Women and Literature in Africa, the Arab world, Asia, the Caribbean and Latin America. London: Alison \& Busby, 1985.

Uko, I. “A Failed Sexual Rebellion” New Women's Writing in African Literature. Ed. Ernest N. Emenyonu. No 24.England: James Currey Ltd, 2004.

Whittaker, David and M Msiska. Chinua Achebe's Things fall Apart. USA and Canada: Routedge, 2007. 